\title{
Pembelajaran Konsep Limit Fungsi dengan Strategi Elaborasi Bagi Mahasiswa Matematika FKIP UM Mataram
}

\author{
Abdillah \\ Dosen Progran Studi Pendidikan Matematika Universitas Muhammadiyah Mataram \\ ahmad fawwaz18@yahoo.co.id
}

\section{INFO ARTIKEL}

Riwayat Artikel:

Diterima: 01-09-2017

Disetujui: 25-09-2017

\section{Kata Kunci:}

Elaborasi,

Limit Fungsi

Matematika,

\section{A. LATAR BELAKANG}

Matematika merupakan ilmu universal yang mendasari perkembangan teknologi modern, mempunyai peran penting dalam berbagai disiplin ilmu dan memajukan daya pikir manusia. Perkembangan pesat di bidang teknologi informasi dan komunikasi dewasa ini dilandasi oleh perkembangan matematika di bidang teori bilangan, aljabar, analisis, teori peluang, dan matematika diskrit. Mata Pelajaran Matematika perlu diberikan kepada semua peserta didik mulai dari sekolah dasar sampai perguruan tinggi, sehingga dapat membekali peserta didik agar mampu berpikir logis, analitis, 
sistematis, kritis, dan kreatif. Salah satu mata kuliah wajib bagi mahasiswa pendidikan matematika adalah Analisis Real. Materi Kuliahan Analisis Real diantaranya membahas tentang limit dan kekontinuan. Namun kenyataan yang ada banyak mahasiswa kesulitan dalam mengikuti perkuliahan terutama pada konsep limit fungsi. Mahasiswa lebih cenderung menghafal definisi maupun teorema tanpa bisa menjelaskan atau membuktikan bagaimana teorema tersebut diperoleh. Dalam upaya mengatasi kesulitan dan permasalahan yang dihadapi mahasiswa dalam proses belajar mengajar, dosen sebagai seorang pendidik harus memiliki strategi agar mahasiswa dapat belajar secara efektif dan efisien, mengena pada tujuan pembelajaran yang diharapkan. Salah satu langkah untuk memiliki strategi ini, guru dan dosen harus menguasai teknikteknik penyajian atau biasa disebut dengan model pembelajaran.

Model pembelajaran yang akan digunakan harus selalu diawali dari situasi nyata di dalam kelas. Berdasarkan kenyataan yang ada, dunia pendidikan mulai mengubah paradigmanya untuk menggunakan pendekatan konstruktivistik. Dalam pandangan konstruktivisme, siswa harus secara individual menemukan dan mentransfer informasi-informasi yang kompleks apabila mereka harus menjadikan informasi itu menjadi miliknya sendiri. Salah satu implementasi dari pendekatan konstruktivistik ini adalah dikembangkannya model pembelajaran learning cycle. Ada lima tahap dalam pembelajaran model learning cycle yang terdiri dari tahap engagement yaitu guru berupaya menumbuhkan minat dan rasa ingin tahu siswa terhadap suatu konsep dengan pengajuan obyek-obyek nyata atau permasalahan kontekstual. Tahap kedua adalah exploration yaitu guru memberikan kesempatan kepada siswa untuk bekerja sama menyelesaikan masalah tentang materi yang dipelajarai, guru sebagai fasilitator. Selanjutnya tahap explanation yaitu siswa menjelaskan jawaban dari permasalahan yang diperoleh dari tahapan sebelumnya yang berkaitan dengan materi yang diberikan. Tahap keempat adalah elaborasi dimana pada tahap ini, siswa menerapkan konsep yang telah diketahuinya dalam situasi baru. Pada tahap akhir terdapat tahap evaluasi yaitu proses evaluasi yang dilakukan pada seluruh proses mengajar.

Dengan demikian jika kita kaitkan model pembelajaran learning cycle dengan pembelajaran konsep limit fungsi pada Mata Kuliah Analisis Real, maka tahap yang efektif digunakan adalah tahap elaborasi. Hal ini disebabkan karena mahasiswa pada dasarnya telah mengenal definisi maupun teoremateorema tentang limit fungsi, yaitu ketika mahasiswa menempuh Mata Kuliah Kalkulus I dan sekarang tinggal mengarahkan mereka bagaimana mengaplikasikan definisi yang telah diketahuinya dalam menyelesaikan soal dan membuktikan teorema-teorema limit fungsi. Pada pembelajaran dengan strategi elaborasi, mahasiswa menambahkan ide tambahan berdasarkan apa yang sudah ketahui sebelumnya. Strategi belajar ini efektif digunakan apabila ide yang ditambahkan sesuai dengan penyimpulan. Implikasi dari pembelajaran ini adalah mendorong mahasiswa untuk menyelami informasi itu sendiri, misalnya untuk menarik kesimpulan dan berspekulasi tentang implikasi yang mungkin (Ormord, 2006). Pembelajaran dengan strategi elaborasi memungkinkan mahasiswa lebih mudah memahami konsep limit fungsi secara mendalam karena pada dasarnya mahasiswa telah memiliki pengetahuan-pengetahuan dasar tentang limit fungsi yang telah dipelajarinya saat menempuh Mata Kuliah Kalkulus I. Hanya saja sekarang bagaimana seorang dosen dalam merancang pembelajaran dengan strategi elaborasi mampu memancing dan melahirkan ide-ide atau pengetahuan baru dari pengetahuan sebelumnya yang telah dimiliki mahasiswa dalam mengkaji konsep limit fungsi lebih mendalam.

Berdasarkan uraian di atas, maka peneliti melakukan rumusan masalah bagaimana mendesain dan menerapkan pembelajaran dengan strategi elaborasi pada konsep limit fungsi bagi mahasiswa semester VI Program Studi Pendidikan Matematika Universitas Muhammadiyah Mataram tahun ajaran 2016/2017. Penelitian ini diharapkan dapat bermanfaat bagi dosen, khususnya bagi dosen yang terlibat langsung dalam penelitian ini yaitu sebagai pengalaman dalam mengembangkan suatu prosedur pembelajaran dikelas. Bagi dosen lain secara umum, penelitian ini diharapkan dapat memberikan informasi dalam mengembangkan suatu prosedur pembelajaran dikelas. Bagi peneliti lain, penelitian ini diharapkan dapat memberikan masukan jika ingin melakukan penelitian. Bagi mahasiswa pendidikan matematika, penelitian ini diharapkan dapat memberikan informasi dalam mengembangkan suatu 
prosedur pembelajaran dan dapat dijadikan sebagai referensi dalam membuat karya ilmiah.

\section{B. METODE PENELITIAN}

Penelitian ini termasuk penelitian tindakan kelas (Action Research). Penelitian Tindakan kelas (PTK) adalah suatu penelitian yang dilakukan oleh guru atau dosen di dalam kelas dengan tujuan untuk memperbaiki kinerja sebagai guru atau dosen, sehingga hasil belajar siswa atau mahasiswa menjadi meningkat (Wardani, 2003:36). Penelitian tindakan kelas memiliki karakteristik penting. Aqib (2006:13) mengemukakan karakteristik penelitian tindakan kelas, yaitu: (1) didasarkan pada masalah yang dihadapi guru dalam pembelajaran, (2) dilaksanakan dengan cara berkolaborasi antara peneliti dengan guru kelas atau teman sejawat, (3) dalam pelaksanaannya peneliti melakukan refleksi, (4) dilaksanakan untuk memperbaiki kualitas proses pembelajaran, dan (5) dilaksanakan dengan rangkaian langkah-langkah dalam suatu siklus pembelajaran.

Setelah mengkaji hasil refleksi awal, mengidentifikasi permasalahan, mengkaji teori-teori yang relevan, serta merumuskan fokus penelitian, dilanjutkan dengan merancang rencana pelaksanaan pembelajaran, lembar kerja mahasiswa, lembar observasi aktivitas mahasiswa, dan aktivitas dosen, wawancara, instrumen tes hasil belajar, serta lembar validasi perangkat pembelajaran dan instrumen penelitian. Penyusunan instrumen penelitian yang di dalamanya ada instrumen pembelajaran mengacu pada tujuan penelitian yang ingin dicapai.

Data yang dikumpulkan dalam penelitian ini merupakan hasil kegiatan yang berhubungan dengan pelaksanaan pembelajaran konsep limit fungsi dengan menggunakan strategi elaborasi. Data yang dikumpulkan dalam penelitian ini meliputi: (1) hasil kegiatan mahasiswa dalam kegiatan pembelajaran berupa penyelesaian soal-soal baik soal tes awal, latihan-latihan maupun evaluasi akhir, (2) hasil wawancara dengan subjek penelitian pada akhir setiap tindakan, (3) hasil observasi yang memuat catatan tentang kegiatan pembelajaran, baik yang berhubungan dengan mahasiswa maupun berhubungan dengan dosen. Sumber data dalam penelitian ini adalah mahasiswa semester VI Program Studi Pendidikan Matematika Universitas Muhammadiyah Mataram tahun ajaran 2016/2017 yang mengikuti pembelajaran dan tes tentang pembelajaran limit fungsi dengan strategi elaborasi. Prosedur pengumpulan data yang digunakan dalam penelitian ini adalah observasi aktivitas dosen dan mahasiswa dan tes akhir akhir yang dilakukan pada akhir pembelajaran. Setelah data terkumpul, maka data perlu segera dianalisis. Analisis data yang dilakukan dalam penelitian ini adalah analisis data kualitatif dan kuantitatif. Data ini dianalisis dengan mereduksi data, menyajikan data, dan menyimpulkan data.

Perangkat pembelajaran dan instrumen penelitian dikatakan valid jika berdasarkan hasil analisis data hasil validasi diperoleh minimal dua dari tiga validator menyatakan perangkat pembelajaran dan instrumen penelitian telah valid. Data aktivitas dosen dan aktivitas mahasiswa diperoleh dari kegiatan observasi yang dilakukan observer selama pembelajaran berlangsung. Aktivitas dikatakan baik jika persentase nilai rata-rata (NR) aspek yang di nilai berada pada kategori baik dan sangat baik. Dengan demikian, maka hasil analisis data yang tidak memenuhi dari salah satu kategori tersebut akan dijadikan bahan pertimbangan untuk memperbaiki pada tindakan berikutnya. Data tentang hasil belajar mahasiswa diperoleh dari hasil tes tertulis mahasiswa tiap akhir tindakan dan tes akhir pembelajaran. Setelah hasil tes mahasiswa didapatkan, hasil tes mahasiswa diberi skor sesuai pedoman penskoran.

Berdasarkan kriteria ketuntasan belajar, hasil tes akhir pembelajaran dikatakan tuntas secara klasikal apabila mahasiswa mendapat skor $\geq 65$ (dari rentang skor 0 - 100) paling sedikit 80\% dari jumlah mahasiswa yang mengikuti tes pada pembelajaran dengan strategi elaborasi pada konsep limit fungsi. Pelaksanaan pembelajaran dikatakan berhasil jika hasil observasi aktivitas dosen dan observasi aktivitas mahasiswa pada masing-masing tindakan berada pada kategori sangat baik atau baik, serta hasil tes akhir pembelajaran tuntas secara klasikal.

\section{HASIL DAN PEMBAHASAN}

\section{Hasil}

Hasil belajar mahasiswa dalam memahami konsep limit fungsi dilihat melalui hasil tes akhir dan melalui evaluasi yang dilakukan selama proses pembelajaran. Evaluasi ketika proses pembelajaran berlangsung dilakukan ketika dosen melakukan tanya jawab dengan mahasiswa, ketika 
mahasiswa mengerjakan LKM, maupun ketika mahasiswa berdiskusi dengan temannya.

Pada pertemuan pertama dan kedua, beberapa mahasiswa masih kesulitan dalam belajar. Hal ini tampak dari hasil belajar mahasiswa ketika mengerjakan LKM dan ketika dosen mengajukan beberapa pertanyaan secara lisan terhadap beberapa mahasiswa. Ketika dosen mengajukan pertanyaan, mahasiswa belum mampu menjawab secara langsung bahkan harus membutuhkan waktu yang cukup lama dalam menjawab. Ketika ada mahasiswa yang kesulitan menjawab pertanyaan yang diberikan, dosen memberikan ilustrasi-ilustrasi sederhana untuk membantu mahasiswa menjawab pertanyaan yang diberikan.

Secara umum hasil belajar mahasiswa selama proses pembelajaran didukung karena pembelajaran yang dilakukan terstruktur dan efisien. Pembelajaran yang dilakukan dimulai dengan mengajukan soal-soal sederhana yang kemudian dilanjutkan dengan memberikan soalsoal yang mengarahkan pada teorema-teorema limit dan akhirnya mahasiswa diminta membuktikan teorema tersebut. Pembelajaran yang diawali dengan mengajukan soal-soal yang sederhana ini sangat membantu mahasiswa dalam memahami materi yang dipelajari.

\section{Pembahasan}

Secara umum hasil belajar mahasiswa selama proses pembelajaran didukung karena pembelajaran yang dilakukan terstruktur dan efisien. Pembelajaran yang dilakukan dimulai dengan mengajukan soal-soal sederhana yang kemudian dilanjutkan dengan memberikan soalsoal yang mengarahkan pada teorema-teorema limit dan akhirnya mahasiswa diminta membuktikan teorema tersebut. Pembelajaran yang diawali dengan mengajukan soal-soal yang sederhana ini sangat membantu mahasiswa dalam memahami materi yang dipelajari.

\section{SIMPULAN DAN SARAN}

Pembelajaran melalui strategi elaborasi yang dapat memahamkan mahasiswa semester VI Program Studi Pendidikan Matematika Universitas Muhammadiyah Mataram tahun ajaran 2016/2017 pada konsep limit fungsi terdiri dari tiga komponen pokok, yaitu orientasi, interpretasi dan penyimpulan. Kegiatan pembelajaran yang dilakukan adalah sebagai berikut: (1) memberikan orientasi tentang pembelajaran yang akan dilaksanakan, menyampaikan topik dan tujuan pembelajaran, (3) dengan tanya jawab memberi motivasi dan apersepsi mahasiswa, (4) dosen melakukan orientasi kepada mahasiswa dengan memberikan permasalahan yang terkait pengenalan konsep limit fungsi, (5) mahasiswa melakukan interpretasi dengan berdiskusi dengan temannya dalam menyelesaikan masalah yang diberikan, (6) mahasiswa mempresentasikan hasi kerja yang diperolehnya, (7) mahasiswa saling memberikan orientasi dengan melakukan tanya jawab berdasarkan hasil yang diperolehnya, (8) dosen memberikan orientasi kepada mahasiswa untuk mengklarifikasi masalah yang muncul, (9) mahasiswa membuat kesimpulan terhadap materi yang telah dipelajari, dan (10) mahasiswa mengerjakan tugas akhir yang diberikan. Tahap (1), (2), dan (3) dilakukan pada kegiatan pendahuluan, tahap (4), (5), (6), (7), dan (8) dilakukan pada tahap kegiatan inti, dan tahap (9) dan (10) dilakukan pada kegiatan penutup.

Berdasarkan pengamatan peneliti dan dua pengamat (observer) pembelajaran konsep limit fungsi dengan strategi elaborasi ditemukan bahwa pada pertemuan I, pertemuan II, dan pertemuan III aktivitas dosen dan aktivitas mahasiswa dalam kriteria baik. Sedangkan tes akhir pembelajaran diketahui bahawa persentase ketuntasan belajar secara klasikal adalah sebesar $87 \%$.

Saran yang dapat disampaikan berdasarkan hasil penelitian ini adalah bagi pengajar, dalam mengajarkan mahasiswa membuktikan konsep limit fungsi dengan definisi hendaknya jangan terlalu fokus untuk langsung melakukan pembuktian, tetapi hendaknya mengarahkan mahasiswa melakukan pengaitan-pengaitan antara pengetahuan yang telah dimilikinya dengan permasalahan yang diberikan, karena hal ini dapat mempermudah mahasiswa untuk mendapatkan gambaran atau arahan dalam melakukan pembuktian. Dalam proses pembelajaran, hendaknya mahasiswa diberikan lebih banyak kesempatan untuk bekerja, bila perlu memberikan kesempatan kepada mahasiswa untuk saling berdiskusi dengan temannya. Pengajar juga harus pandai mengajukan pertanyaan-pertanyaan yang sifatnya mengarahkan tanpa harus memberikan jawaban langsung kepada mahasiswa. Sedangkan bagi peneliti yang ingin meneliti kajian yang sama, hendaknya dapat melakukan penelitian lebih lanjut dengan memperhatikan kelemahan-kelemahan 
30 | JTAM, Vol. 1, No. 1, Oktober 2017, Hal. 26-30

penelitian ini, sehingga peningkatan kualitas belajar

matematika dapat terlaksana secara

berkesinambungan.

\section{REFERENSI}

[1] Arikunto. (2012). Prosedur Penelitian Suatu Pendekatan Praktek. Jakarta: Rineka Cipta.

[2] Degeng, I.N.S. (1997). Strategi Pembelajaran Mengorganisasikan Isi dan Model Elaborasi. Malang: IKIP Malang

[3] Wardani, I.G.A.K., dkk. (2003). Penelitian Tindakan Kelas. Jakarta: Pusat penerbitan Universitas Terbuka.

[4] Wena, M. (2008). Strategi Pembelajaran Inovatif Kontemporer. Malang, Bumi Aksara.

[5] Lawson, A.E. (1995). Science Teaching and The Development of Thingking. California: International Thomson Publishing.

[6] Ormord. (2009). "Strategi Pengajaran Pembelajaran Sains". http://www.bpkpenabur.or.id/jurnal/05/063071.pdf. 